\title{
Jobofifetime
}

\section{The user experience librarian}

As human beings we consistently seek better experiences. We travel ten more miles to reach a grocery store where we can browse wide aisles in peace. We search for the laundromat with the most comfortable seating, the best-stocked vending machine. We pay more for better customer service and are still surprised when a company makes an extra gesture to keep us satis ed. What is life, if not the search for a day more ful lling than the last?

So what type of experience are academic library users searching for? As college and university libraries across the nation continue their search for a readjusted mission and future outlook, the user experience is something that can weigh heavily on both real and perceived value. As the User Experience Librarian at Georgia Tech, Brian Mathews has spent the last two

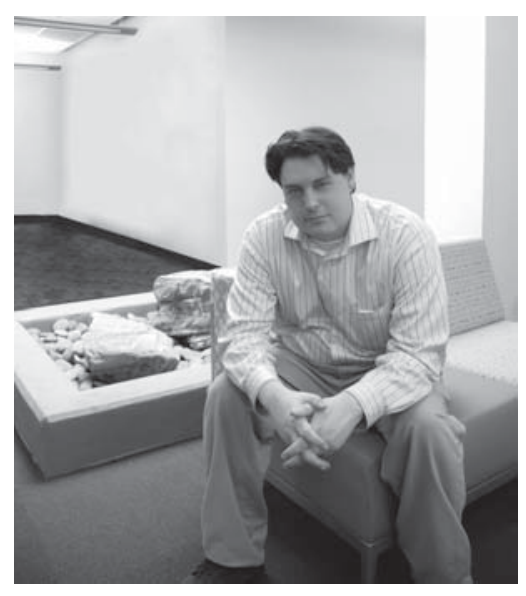

Brian Mathews, user experience librarian at Georgia Tech. found his niche. What appealed to me about librarianship was that it allowed me to work and contribute to an academic purpose, he says, citing his initial love for journalism as the impetus for his interest in research and data.

After the completion of a library-wide strategic plan, the need for a dedicated point-person for assessment and communications at the Georgia Tech Library became clear. With a personal interest in user-experience philosophy, design-thinking, and empathic design (emotional aspects of user-product relationships), Mathews transitioned from the Information Services Department to this newly created position reporting directly to the associate director for public and administrative services. Supervising one full time staff member and one student assistant, Mathews describes years investigating user needs and the library s effectiveness in meeting those needs. My job is to look at the big picture and then to help design a better overall library experience for our users, he says.

Academic librarianship has been a passion for Mathews ever since he worked as an undergraduate book-shelver at the University of Central Florida (UCF). After earning a dual degree in English and History, he took a paraprofessional position at UCF and began the distance graduate program at the University of South Florida-Tampa one year later. Drawn to the thought of publishing, presenting, working in an academic setting, and providing access to mass collections of information, Mathews his unit as a start-up company or design rm. We re very project-oriented, he says, There is a de nite ebb and ow to the work as the semester unfolds.

Some recent projects include a study regarding student laptop usage, a furniture expo to gather feedback on potential renovation furnishings, prototyping the librarys visual identity, and studying students as they prepare for nals. With my job, each week is something different that s what fuels me and that s what I love about it, Mathews confesses.

Erin Dorney is outreach librarian at Millersville University of Pennsylvania. Have a story idea for Job of a Lifetime? E-mail Erin Dorney at erin.dorney@millersville.edu. A podcast interview with Mathews is available online. 
With consistent user interaction, Mathews position boils down to designing a better library. He is currently working on The DNA Project, an attempt to decode the library experience. Through student interviews (two per week), Mathews learns about perceptions of the library, class assignments, life on campus, technology, and more. Sessions typically last from 30 minutes to an hour. The best session I had was nearly three hours long I had to cancel a meeting, but the data was just too valuable, he says, I don t just want to measure user perceptions, but discover how those perceptions were formed. Why do they use the library? What triggers usage? What do they know, and how did they nd out about it? Once they ve discovered something, did they use it again? Did they tell others about it?

The goal of The DNA Project is to determine why certain individuals become regular library users, while others rarely use library resources and services at all. The identi cation of patterns has the potential to change everything, says Mathews, ... how we do instruction, how we promote and provide services, perhaps even the way we de ne academic libraries.

On advice for the future, Mathews is a proponent for purposeful change. Assessment is a mess. We re asking the wrong questions. We re measuring the wrong things, he says. Citing the recent ethnographic work done at the University of Rochester (Studying Students, ISBN 978-0-8389-8437-6) as the most important library science book published this decade, Mathews advocates for librarians to think differently, expanding toolkits and intentions to seek emotional and personal connections with users (concepts traditional library assessment ignores).

For Mathews, staying current is more than a matter of belonging to library associations and organizations. He subscribes to Wired and Fast Company magazines, reads Advertising Age, the Chronicle of Higher Education, I.D. (The International Design Magazine) and UX Magazine, along with campus publications and select library blogs. I see myself as a student of communication; it fascinates me to see how different people present their ndings how a scientist reports her data, how an engineer tackles a program, or how a historian describes a situation the content is different, but it $\mathrm{s}$ all storytelling, he says, explaining his interdisciplinary reading habits.

He is also a member of AIMA (Atlanta Interactive Marketing Association), an integral factor in his development of interest in the user experience. Gaining face time with marketing professionals, designers, and managers from companies like Coca-Cola, Turner Broadcasting, Delta, Target, Facebook, and MTV helped Mathews see the bigger picture: If I had to point to one thing that boosted my career the most it is probably these interactions. AIMA opened up my eyes to how insulated academic librarians tend to be.

In addition to his responsibilities at Georgia Tech, Mathews nds time to maintain the popular blog The Ubiquitous Librarian (theubiquitouslibrarian.typepad.com) and contribute to the group blog Designing Better Libraries (dbl.lishost.org/blog). His rst book, Marketing Today's Academic Library: A Bold New Approach to Communicating with Students (ISBN 978-0-8389-0984-3), was published in March 2009 by ALA Editions. I don $t$ see it so much as a marketing book, but rather a discussion on building relationships with library users, says Mathews.

In June 2009, Mathews will leave his position as user experience librarian at Georgia Tech to 11 the role of assistant university librarian for outreach and academic services at the University of California-Santa Barbara. His new position will include oversight of the library s outreach and marketing efforts, coordination of assessment, and leading Web site development. Hopefully it will be a chance to further develop my leadership and knowledge of libraries, he says of the change.

The interdisciplinary nature of the profession is what provides Mathews with passion and inspiration, including the elds of anthropology, design-thinking, psychology, psychodemographics, statistics, and ergonomics among others. His exible and forward-thinking attitude just about sums it up; Just when I think I ve gure out what a librarian is all about, everything changes. I love that, though. 